\title{
COMMUNICATIVE PERSPECTIVE OF TERMINOLOGICAL METAPHORS ${ }^{1}$
}

\section{PERSPECTIVA DE LA COMUNICACIÓN DE LAS METÁFORAS ${ }^{1}$ TERMINOLÓGICOS}

\author{
Luciana Pissolato de Oliveira \\ Pontificia Universidad Católica de Chile \\ lupissolato@uc.cl
}

\section{Resumen:}

Las metáforas terminológicas, lejos de ser un factor que conduce a la oscuridad conceptual, actúan como mecanismos cognitivos, guiando la construcción del conocimiento científico y también su difusión en situaciones de asimetría de conocimiento. Según su ambiente de producción y recepción, adquieren diferentes funciones y delimitaciones semánticas, que son propias de su naturaleza. En el presente artículo, observaremos las características de estas metáforas en dos espacios discursivos, el científico y el de la divulgación científica, con vistas a resaltar las particularidades de estas metáforas. Además, describiremos la influencia de aspectos cognitivos, lingüísticos e comunicativos en su formulación y actualización en el discurso de la ciencia.

Palabras clave: terminología, metáfora, géneros textuales, discurso científico.

${ }^{1}$ Artículo que forma parte del Proyecto Fondecyt Inicio 2016 titulado: Metáfora terminológica y traducción especializada: una propuesta para la elaboración de nuevas estrategias de traducción. 


\section{Abstract:}

Terminological metaphors, far from being a factor that leads to conceptual obscurity, act like a cognitive hook, since they guide the construction of knowledge and the development of science, and its diffusion in situations of asymmetrical knowledge. According to its production environment and reception, they acquire different functions and semantic delimitations, which are distinctive of their own nature. In the present article, we observe the characteristics of these metaphors in two discursive spaces, the scientific and the popularization of science, with the aim of highlighting the particularities of these metaphors. Additionally, we describe the influence of cognitive, linguistic, and communicative aspects in their formation and improvements within the scientific discourse.

Keywords: terminology, metaphor, textual genres, scientific discourse.

\section{Introduction}

Due to their orientation to scientific accuracy, sciences and techniques traditionally used literal language to express more objectively and effectively their theories, and more particularly their terminology. According to the Wusterian perspective (General Theory of Terminology, 1931), metaphors, and figurative language in general, were considered as subjective and ambiguous entities and, therefore, lacking the scientific rigor that was required by specialized communication.

With the advent of the Communicative Theory of Terminology, by Maria Teresa Cabré (1998, 1999), and culminating with the Sociocognitive Theory of Terminology, by Rita Temmerman (2000), Terminology is remolded and 
supported by communication, cognitive, and language theories - additionally some traces of this new model can be found in Socioterminology by Gaudin (1993). The term is then seen as a dynamic unit, and should be understood according to linguistic, cognitive, and social biases. Driven by Cognitive Linguistics, which in the '1970s and 1980s', already dealt with the metaphor as a result of processes of categorization and cognition, terminological metaphors began to be recognized, and moreover, perceived as necessary for the sciences. More recently, Gerard Steen (2013) proposes a new and improved theory of metaphor, considering not only cognitive and language factors, but also their communicative and social aspects, which offers "new perspectives on the interaction between social, psychological and linguistics properties and functions of metaphor in discourse" (p. 27).

Metaphor is seen, within the field of Terminology, as an expression of the categorization and conceptual organization of knowledge. Such metaphorical conceptual system, which guides the terminological naming process, can be observed when concepts are specialized by using the same root-metaphor, like DNA IS INFORMATION IN A ATLAS OF MAPS, that generates several terminological metaphors like genomic map, chromosome mapping, marker gene, genetic distance, and so on. These linguistic expressions can be evidence that there is, indeed, an underlying conceptual metaphor managing the processes. According to Sergio Pena, geneticist and columnist for the online magazine Ciência $\mathrm{Hoje}^{2}$, the metaphorical view of the human genome as a library (THE HUMAN GENOME IS A LIBRARY) has been quite fruitful for cell biology, since linguistic, grammatical, and bibliographical metaphors have been widely used in describing genetic processes. According to the author, "a

\footnotetext{
2 Online Brazilian magazine on popular science, available in: http://cienciahoje.uol.com.br/
} 
informação do DNA codificador no genoma (os genes) está escrita em um alfabeto de 4 letras (bases nitrogenadas) e é transcrita em RNA mensageiro e posteriormente traduzida para a linguagem das proteínas, que compreende um alfabeto de 20 letras (aminoácidos)"3. (Ciência Hoje Online. Web, 28 sep. 2015).

Nonetheless, it is noteworthy that in the present work we will analyze terminological metaphors from a linguistic and communicative point of view, through the description of discourse and how it reflects such metaphorical concepts. That means that we will not deal with conceptual metaphors a priori, since our intention is to understand the functional aspects of metaphors based on observations of their employment, generating information for theories that deal more specifically with the conceptual view of metaphors. However, it is assumed that these metaphorical linguistic expressions give us clues on the behavior of our conceptual system, which linguistically reflects conceptual metaphors (Oliveira, 2009). According to Steen (1997) ' [...] cognitive linguistics are going out of their way to show that linguistic metaphor is fundamentally conceptual, but that in doing so, they have neglected the method for showing how they get from linguistic metaphor to conceptual metaphor in the first place' (p. 58).

The analysis is based on a corpus, collected from 2000 to 2010, of Molecular Genetics and its technologies. It is important to mention that the corpus is composed by two subcorpora from Brazilian Portuguese, of scientific and

\footnotetext{
3 " [...] the information on the DNA encoding into the genome (genes) is written in a four letter alphabet (nitrogenous bases) and is transcribed into messenger RNA and subsequently translated into the language of proteins comprising an alphabet of 20 letters (amino acids)".
} 
popular science. The first corpus includes dissertations and theses, scientific articles published in journals and teaching materials for high school, and the second one is constituted by articles and texts published by the magazines Super Interessante, Ciência Hoje online and the supplement Ciência from newspaper Folha de S. Paulo and Estado de S. Paulo. To carry out a proper and accurate work of identification, selection and subsequent analysis of the data, we used a mixed method -linguistic and computational-, proposed by Deigman (2005).

\section{Metaphor and Terminology}

Metaphors, according to cognitive theories, are characterized as fundamental cognitive tools in the apprehension and formulation of concepts. They are a cognitive mechanism in which a domain of experience is partially mapped or projected in another domain of experience, and this second domain is partially understood in terms of the first one (Barcelona, 2003).

Terminological metaphors are similarly produced, either in a scientific environment or in the dissemination of a particular science. However, we realize that when metaphors are used in different discursive situations, and therefore in different textual genres, they must be understood accordingly to their communicative functions and consequently to their production and reception environment. This happens because the function of each one of them is crucial to their formation and, therefore, it assumes the use and update of different cognitive biases in its conception. 
We will present, in the following sections, some characteristics of metaphorical use in both domains, which results from the analysis of our corpora ${ }^{4}$.

It is worth clarifying that, although we are not dealing with conceptual metaphors, the model proposed by Fauconnier (1997) to explain mappings between the source and target domains is also very functional in demonstrating analogical relations within the metaphorical terminology of Molecular Genetics and another fields of knowledge. According to the author, 'The mapping between domains is the heart of the human cognitive faculty of producing, transferring, and processing meaning' (p. 22). In our case, we will notice that source domains will be represented by concepts from other domains of expertise (more stable) or by other concepts, based on our physical experience, in accordance with deliberated or non-deliberated (Steen, 2013) use of metaphors and communicative purposes.

\subsection{Scientific metaphors}

Due to their important heuristic and cognitive potential, since their most prominent function is to participate in the development of scientific hypotheses and models, scientific metaphors are revealed primarily in two ways in our scientific corpus:

a. through new associations for pre-existing referents as in código de barras molecular (molecular barcode), gene de manutenção (housekeeping gene), gene estampado (imprinted gene), percepção de quórum (quorum sensing) or

\footnotetext{
4 The corpus, designed for my $\mathrm{PhD}$ thesis (cf. Oliveira, 2012), was described previously in the Introduction of the present work.
} 
$b$. through the revival of metaphors that were taken as dead, or cathacreses. According to Silva (1997), these metaphors are the most important ones from a cognitive point of view and act as important cognitive models. We can observe this case in formations that employ elements like âncora (anchor), esqueleto (skeleton), família (family), pistola (gun) and tronco (stem).

Overall, conceptualizations of new scientific facts are made by projections of relations of similarity between concepts of a source domain and a target domain, and those projections are, in most cases, partial. An example can be illustrated by the term estampagem genética (genetic imprinting), shown below, where the mark that is generated by the stamping process is a model for the conceptualization and naming of estampagem genética, a process through which a gene is marked with its parental origin - a technique used in Genetic breeding or for reproduction of species near extinction:

ESTAMPARIA

ESTAMPAGEM

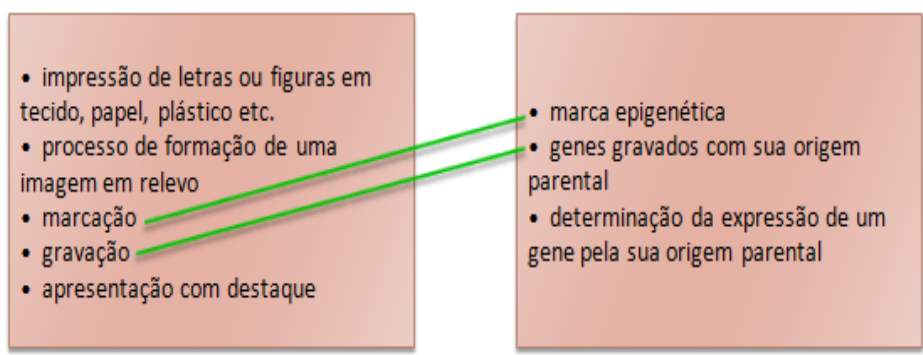

Figure 1. Partial similarity between concepts from different domains.

GENÉTICA

ESTAMPAGEM

- genes gravados com sua origem parenta

- determinação da expressão de um gene pela sua origem parental 
However, there are cases in which the coverage of both domains is complete, with a relation of total similarity between the concepts of both fields, source and target. This is the case for the term impressão digital de DNA (DNA fingerprinting), presented as follows:

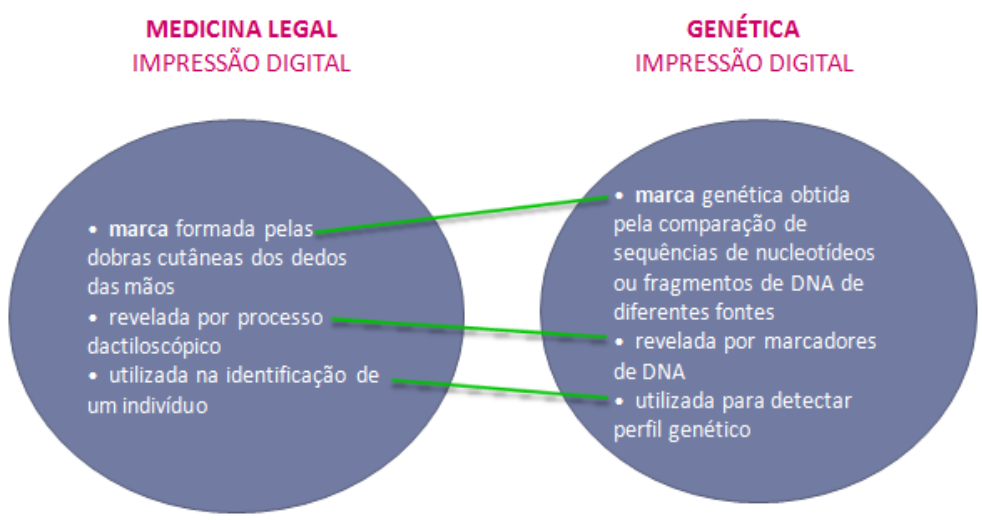

Figure 2. Total similarity between concepts from different domains

In this case, Genetics borrows from a specialized domain, Legal Medicine, a model of conceptualization for the identification of genetic profiles, which is widely used in forensic medicine for the identification of suspects.

There are also cases in which motivation for conceptualization and naming is based on observation of simple everyday experiences, such as walking, jumping, and sliding. This is the case of andar no cromossomo (chromosome walking), saltar no cromossomo (chromosome 
jumping), and deslizamento de replicação (replication slippage). In the first example, we have a technique that operates with repetitive overlapping of fragments of chromosomes, whose evolution is similar to human walking. Nonetheless, in the second case, the movement is up and down, and looks like a jump. In deslizamento de replicação (replication slippage), a mechanism that enables DNA replication, the movement is seen as a sliding. An illustration of the first two techniques is presented below:

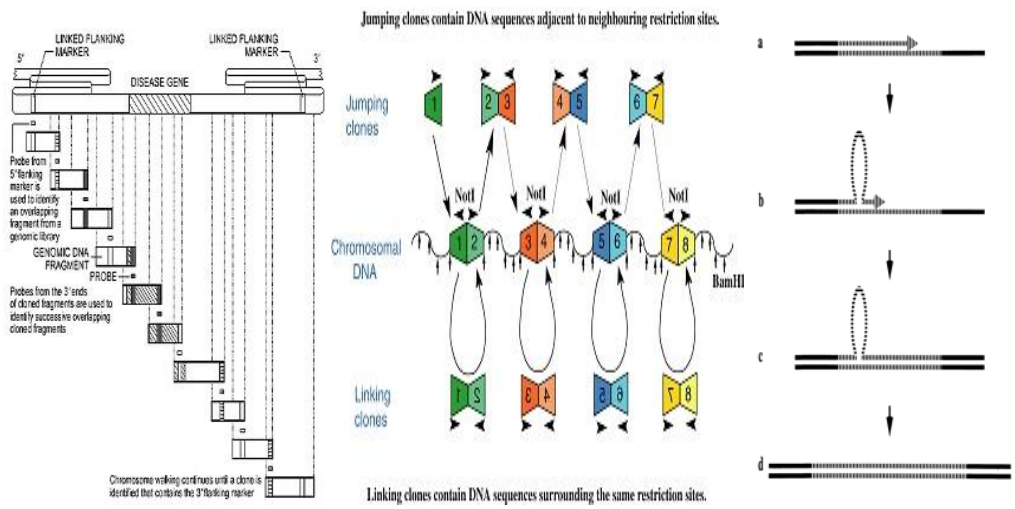

Figure 3. Techniques chromosome walking ${ }^{5}$, chromosome jumping, and replication slippage ${ }^{6}$.

As we can observe, metaphors that build theories (Boyd, 1993) are predominantly cognitive in the sense that they take part in the construction of a concept, or, in a previous stage, in the understanding and in the creation of a hypothesis about a particular scientific phenomenon. In general terms, the conceptual assimilation is given by the observation of functional or visual similarities in relation to

\footnotetext{
${ }^{5}$ Image by Law, Science \& Public Health Program Site

${ }^{6}$ Image by American Heart Association
} 
the source concept, such as in the case of DNA fingerprinting or chromosome walking, respectively.

In the following section, we will see that metaphors of popular science are formed from different criteria, and, consequently, serve different functions in the scientific discourse.

\subsection{From scientific to popular science: a continuum}

When we analyze the naming or the cognitive line through which a term goes from scientific to popular science, we find two different situations: a) the original term is erudite and it metaphorizes on this continuum, or b) the original term is metaphorical and it remetaphorizes, aiming at adaptation to the communicative situation. We will see, however, that in these cases the tasks of metaphors are other than heuristics or cognitive, which predominate in strictly scientific environments.

Both situations can be illustrated with the same example, for which we will use the term transposon. We will notice that such 'metaphorical evolution' can be explained due to communication needs that will be imposed on this path. In a specialized environment, in which communication takes place among specialists, the erudite term is widely used and preferred:

“O gene marcador de seleção mais comumente usado é o aphA2 ou npt11, isolado do tranposon tn5 de Escherichia coli [...]. ", (Genômica, 2004);

\footnotetext{
${ }^{7}$ The most-used marker gene is aphA2 or npt11, isolated of transposon tn5 of Escherichia coli [...].
} 
However, in a different discursive situation, especially in the context of learning, it may be necessary to use a metaphor. This is because a student, becoming specialized in the field, faces very abstract issues, and metaphors can help in this process of knowledge transmission and acquisition, since they translate more clearly the concept to be acquired, based on a more familiar concept. In this communicative situation, the term gene saltador (jumping gene) arises, a metaphor for transposon, used in scientific context:

"Também não se entende direito, ainda, o comportamento dos transposons - os genes saltadores, que pulam de um cromossomo para outro [...]. Pensavase que os genes saltadores funcionassem em lugares muito específicos, do mesmo tecido. Mas não.", (Revista Fapesp, 2000)

We observe that, in pedagogical situations as the one described above, the terms erudite and metaphorical usually co-occur, allowing the future expert to understand the concept and fully digest the unique terminology of the field.

However, there is room also for a new metaphor, which occurs when that scientific knowledge is transported to vehicles for popular science: the characteristics of this kind of journalism and the public to which these texts are addressed require a big effort in the communication of science, and it must be more exciting for their readers. The use of scientific terminology would cause serious noise communication, and the pedagogical terminology appears to be very flat, which is why intentional and ornamental

\footnotetext{
${ }^{8}$ The behavior of transposons is not yet clear- the jumping genes, which jump from one chromosome to another [...]. It was thought that jumping genes worked in very specific places within the same tissue. But, that was not true.
} 
metaphors abound in this context. In addition to fulfilling a didactic role, they carry a stylistic function, which is very important for this purpose, since it must attract the reader's attention to the generally complex and obscure ways of science. In this context, therefore, the term transposon, which is already metaphorized into gene saltador (jumping gene) in didactical situations, remetaphorizes, once more, into gene canguru (kangaroo gene), acquiring some special color:

"Alguns estudos indicam que esses elementos genéticos móveis e as sequências deles derivadas podem corresponder a até $45 \%$ do genoma humano. Além disso, diversas doenças [...] têm sido associadas com esses "genes cangurus". (Ciência Hoje Online. Web 28 sep. 2015)

A scheme represents different mappings occurring in the formation of gene canguru. We can recognize one mapping between the concepts tranposon and gene saltador and another one between gene saltador and gene canguru.

9 Some studies indicate that these mobile genetic elements and their derived sequences can correspond to up to $45 \%$ of the human genome. Moreover, several diseases [...] have been associated with these "kangaroo genes". 


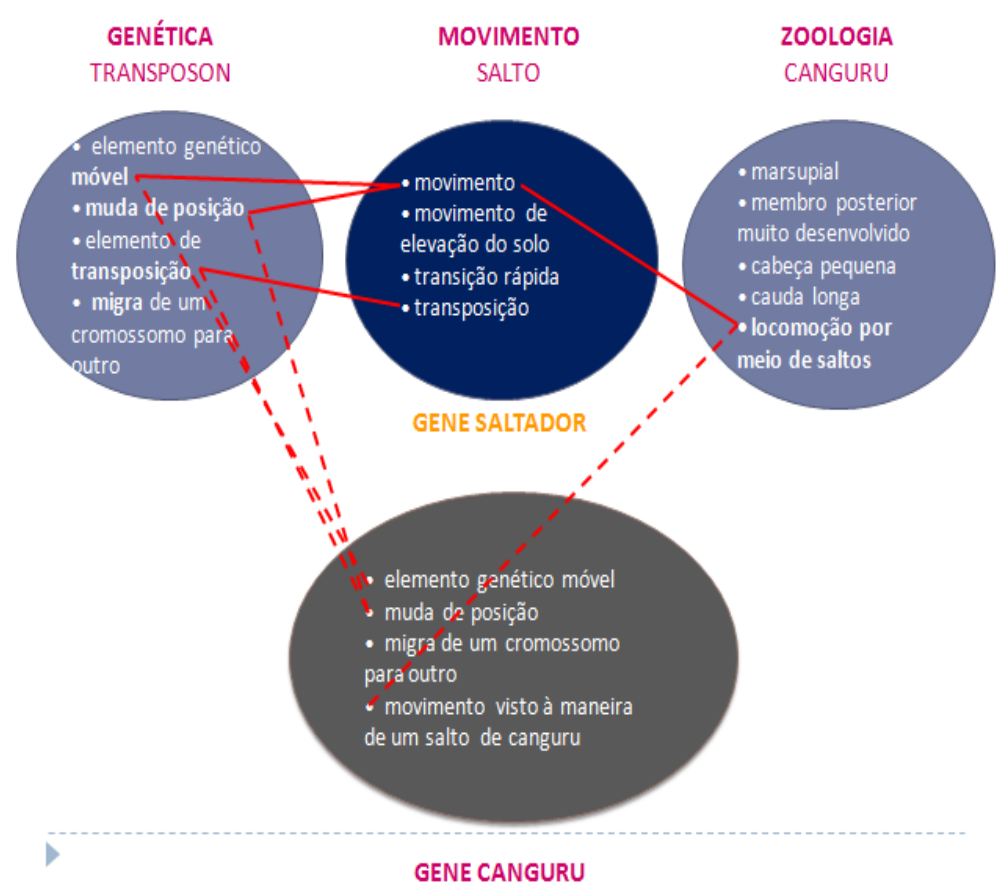

Figure 4. Double similarity relation in the formation of gene canguru (kangaroo gene)

In such cases, unlike what happens in the mappings between domains in conceptual metaphors, there is no formation of independent concepts (as shown by the Theory of Conceptual Integration, by Fauconnier and Turner, 2002). For these mappings, semantic features of the same concepts are emphasized in each (re)metaphorization in order to accomplish certain functions: gene saltador highlights the movement of the genetic element, which resembles a jump, in order to describe the main aspects of the concept, and have 
didactic function. In gene canguru, derived from gene saltador, the most valuable semantic trait is the visual aspect (borrowed from an alien domain, the zoology) through the analogy of an animal that moves by jumping, prototypically earning a new and stylistic function.

We can say that the creation of the jumping gene metaphor has a cognitive root, in the sense that it recuperates the semantic of the Latin prefix trans-, in transopon, which indicates movement; as such, we can think about the metaphor as an adaptation to the communicative needs of the pedagogical discourse that is not unlinked from the original concept.

On the other hand, the creation of the kangaroo gene metaphor is evidently new, conscious, and intentional, and as such, dependent on authorship, which reveals its stylistic origin. This type of metaphor, different from what occurs with cognitive metaphors, permits a wider flexibility in its interpretation, and consequently brings with it a narrower fidelity to scientific information. In other words, what is gained is the aesthetic sense is lost in the conceptual.

Finally, it is worth making clear that this has not to do with evaluating the metaphor as either a "good metaphor" or a "bad metaphor"; the idea is, rather, to delimitate its nature and functionality according to its production and reception environment.

\section{Concluding remarks}

When taken in the Aristotelian sense, the metaphorical use in the discourse of science is considered unscientific. Thus, when considering metaphors as rhetorical and stylistic figures, we relate them to subjectivity and lack of rigor in 
specialized communication. We see, however, that terminological metaphors actually used by sciences play a role quite different from the ones traditionally used, and that role is being described and theorized by the most current segments of terminology.

We note that they have mainly heuristic, cognitive, and denominational functions, or didactic, in communicative situations which require such use. According to Oliveira (2009), they are, therefore, conventional metaphors, not open to subjective interpretations and that do not require a special intellectual task of interpretation, or a particular inference effort, but they are invariably understood among experts, because they are products from collective insight of the entire scientific community (Gibbs, 1994).

Moreover, these metaphors tend to be lexicalized very rapidly, since they are embedded in a theory and can be widely disseminated; thus, the metaphorical sense of a term will fade for the expert and for the community that uses this terminology (Alves, 1991) - a phenomenon that is also abundant in the general language.

Metaphors used in vehicles for popular science, in turn, have a different status from those in specialized contexts, since its primary function is rhetorical and for stylistic purposes. We cannot fail to notice that they play a very important educational role, taking the reader closer to the reality of science, which is often intangible to them. Note that they are effectively used in an Aristotelian sense and, therefore, are occasional, deliberated, and totally dependent on authorship, as can be seen in the following example, which is the title and subtitle of a popular science article that denotes great arbitrariness in lexical choices: 'Júnior Baiano e Ronaldinho Gaúcho juntos! Conheça um tipo de célula recém-descoberta (sic) que tem a função de zagueiro $e$ 
maestro do time.' 10 (Ciência Hoje online, 28/09/2015). In this sense, these metaphors, although originating from scientific discourse, in their continuum into popular science differ from the ones of science discourse (conventional and unconscious) by being absolutely original and innovative, which requires a bigger effort in understanding the mapping.

We find, therefore, that different discursive contexts in which a term appears are crucial for the activation of its conceptual or rhetorical content, even in the field of terminology (in its scientific or popular science context). According to Ciapuscio (2003), the functionality of the textual class (of popular science or massive, aiming at the acceptance or diffusion of knowledge) and the communicative situation (profile of the recipient, text type, etc.) are decisive for the presence of certain conceptual features. Thus, most of the terms presented in articles of popular science have a significantly reduced conceptual density, due to the time of access to information by the speakers, since those may be less technically informed about the domain, amongst other things. Another behavior observed in the metaphors of popular science is that the conceptual contents that are activated are mainly those accessible by the senses: sight, smell, touch, taste, etc., which are categories bound to sensory perception. Still in accordance with the author, description and explanation geared to the common experience is a recurrent strategy in texts of popular science while the scientific metaphors can also be guided through other areas of knowledge (in cases presented earlier, in Stamping, Forensic Medicine, but also in Computer Science, Cartography, Anatomy, among others).

\footnotetext{
${ }^{10}$ Junior Baiano and Ronaldinho together! Learn a kind of newly discovered cell, which works respectively as a fullback and quarterback.
} 
In sum, we believe that looking at these metaphorical linguistic expressions enables us, albeit timidly, to understand the way metaphors act in society, considering their tridimensional aspects and functions: the cognitive, linguistic, and communicative ones.

As a final remark, we have to say that these creative and occasional metaphors coming from popular science sometimes work as a 'trigger' for conceptual evolution, by highlighting some aspects of the source domain that could be very useful for the conceptualization of the target domain (Deigman, 2006), in this case, the genetic theory. Further investigation to determine specific characteristics of metaphor that really fit this purpose would be helpful to describe in a deeper way the potential functions of popular science metaphors.

\section{Bibliography}

Alves, Ieda Maria. "Em torno de um jargão técnico: o economês". Urbano et al (Org.) Dino Preti e seus temas: oralidade, literatura, mídia e ensino.1 ed. São Paulo: Cortez, 2001. 173-180. Impreso.

Barcelona, Antonio. "Introduction". Metaphor and Metonymy at the Crossroads: A Cognitive Perspective. Berlin \& New York: Mouton de Gruyter, 2003. 1-28. Impreso.

Boyd, Richard. "Metaphor and theory change. What is 'metaphor' a metaphor for?" Ortony, Andrew (ed.). Metaphor and Thought. Cambridge: Cambridge University Press, 1993. 481-533.Impreso.

Ciapuscio, Guiomar E. Textos especializados y terminología. Barcelona: Institut Universitari de Lingüística Aplicada, 2003. Impreso.

Fauconnier, G. Mappings in thought and thought. Cambridge University Press, 1997. Impreso. 
Fauconnier, Gilles and Turner, Mark. The Way we Think. Conceptual Blending and the Mind's Hidden Complexities. New York: Basic Books, 2002. Impreso.

Feldman, Jerome. A. From molecule to metaphor. A neural theory of language. Cambridge, MA: MIT Press, 2006. Impreso.

Gibbs, Raymond W. The poetics of mind: Figurative thought, language and understanding. New York: Cambridge University Press, 1994. Impreso.

-------. and Steen, Gerard. Metaphor in Cognitive Linguistics. Amsterdam: John Benjamins, 1999. Impreso.

Lakoff, George and Johnson, Mark. Metaphors we live by. Chicago: The University of Chicago Press, 1980. Impreso.

Oliveira, Isabelle. Nature et fonctions de la métaphore en science. L'exemple de La cardiologie. Paris: L'Harmattan, 2009. Impreso.

Oliveira, Luciana Pissolato. Aspectos linguísticos, comunicativos e cognitivos das metáforas terminológicas: uma análise baseada em um corpus da Genética Molecular. PhD Thesis. Universidade de São Paulo, 2012. Impreso.

Semino, Elena. "The adaptation of metaphors across genres". Review of Cognitive Sciences. Vol 9, 2011. 130152.Impreso.

Steen, Gerard J. "The contemporary theory of metaphor now new and improved." Metaphor and Metonymy revisited beyond the Contemporary Theory of Metaphor. Amsterdam / Philadelphia: John Benjamins, 2013. 27-67.Impreso.

Temmerman, Rita. "Sociocognitive terminology theory". Terminología y cognición. Barcelona: University Pompeu Fabra, 2001.75-92. Impreso. 